\title{
INFLUENCE OF HARVESTING METHODS ON GINNING OPERATION AND FIBER QUALITIES FOR EGYPTIAN COTTON
}

Khalifa, E. M. ${ }^{1}$; R. M. Kholief ${ }^{2}$; M.A Eltawil ${ }^{1}$ and M.A. Neamtallah

1- Agric. Eng. Dept., Fac. of Agric., Kafrelsheikh Univ.

2- Agric. Eng. Res. Inst. (AEnRI), El-Giza, Egypt.

\begin{abstract}
The present study was devoted to investigate the effect of mechanical and manual harvest for Egyptian cotton variety (Giza 86) on ginning process and fiber qualities. Mechanical harvesting was undertaken by using picker harvest John deere 9970. Cleaning operation was carried out at Rice Mechanization Center by using cleaning machine. Whereas, ginning process was conducted at cotton Ginning Research Division, Kafr El-Sheikh province during 2006-2007. Ginning prototype machine was used to study the effect of ginning knife speed, feed rate and fiber moisture content on ginning performance (ginning capacity, ginning outturn, ginning efficiency, ginning energy and fiber qualities).

The best performance for the gin stand machine were obtained at rotational speed of 600 r.p.m $(9.41 \mathrm{~m} / \mathrm{s})$ feed rate of $6 \mathrm{~kg} / \mathrm{h}$ and fiber moisture content of $5.7 \%$ where it gave the following results: a) ginning capacity of $16.93 \mathrm{~kg} / \mathrm{h} . \mathrm{m}$. b) ginning outturn of $44.95 \%$. c) ginning efficiency of $99.33 \%$, and d) ginning energy consumption of about 195.6 w.h.

Whereas the best fiber qualities were obtained at rotational speed of 600 r.p.m, feed rate $12 \mathrm{~kg} / \mathrm{h}$ and fiber moisture content of about $10.32 \%$ and the following indicators were obtained: a) Fiber uniformity of $49.9 \%$. b) fiber elongation of $4 \%$. c) fiber strength of $30.2 \mathrm{~g} / \mathrm{tex}$, and d) color reflectance of $72.9 \%$.

To overcome the labour shortage and the higher wages during harvesting period mechanical harvesting followed by cleaning was recommended which other wise improves some fiber qualities.
\end{abstract}

\section{INTRODUCTION}

Cotton crop is considered as one of the most strategic crop and major staple field crop in Egypt. It is one of the major cash crops and plays a vital role in increasing the Egyptian national income. Cotton lint is the most important agriculture fiber in the world in addition to its importance for oil production from seeds. The Egyptian cotton has excellent qualities. This situation, in fact is the result of an extremely favorable weather, a high fertile soil and irrigation management. During $2004-2005$ the total cotton cultivated area was 776415 feddan* and its produced about 5956790 cantars $^{* *}$ with an average of 7.67 cantars/ feddan (Ministry of Agriculture, General Institution for Direction and Statistics, 2006 in arabic). About 7.5 percent of the produced seeds are used for planting and rest is used for oil extraction and animal feed production. Cotton seed meal is considered a high-protein feed for livestock.

* An Egyptian unit of agricultural area, one faddan $=4200.83 \mathrm{~m}^{2}$

** Cantar $=157.5 \mathrm{~kg}$ raw cotton 
Khalifa E. M. et al.

When seed cotton arrives at the gin it contains dirt, hulls, moisture, leaf fragments, stems and other trash such as weeds and grass. The gin must remove these foreign matters in addition to separate the lint from the cotton seed. Thus the gin plays an important role in the overall mechanization picture. The presence of excessive amounts of trash and other foreign matter reduces the gin turn-out, increases the cost of ginning and lowers the final lint grade. Ginning is the first mechanical process that converts the seed cotton into two salable product; fiber and seed and it's the link between agriculture procedure and industrial process.

Mangialardi (1986) said that foreign matter portion consists of visible and invisible waste components. Visible waste trash and non spinnable fibers, such as fibers attached to motes and seed coat. Fragment, invisible waste is condenser cage (chamber) loss and fly waste. The amounts of lint and foreign matter recovered are calculated as a percentage of original specimens mass.

Munro (1987) stated that cotton harvesting machines are two main types, the spindle picker and striper. The spindle picker which tangles with cotton seed in the open bolls pulling it away from the husk and this type of machines is used for all good quality cotton. The stripper is non selective and harvest every thing that comes on its way, such as bolls husks leaves and some branches.

Mangialardi and Meredith (1990) found that the fiber strength decreased consistently from 26.6 to $22.9 \mathrm{~g} /$ tex from the first harvest date to last harvest date treatments, overall last harvest date treatments producing the lowest strength. Elongation was also lowest for last harvest date treatments. The decrease in the fiber strength between the first and last harvest date cotton treatment was statistically significant.

Eweida (1997) found that feeding the gin stand with seed cotton by hand exhibited the highest gin stand outturn, the lowest ginning time and cracked seed as compared to the belt or the cylinder methods. Also he mentioned that no significant differences in the lint grade, lint color, fiber lint parameters, non lint content or micronaire reading due to the effect of the feeding methods to gin stand with seed cotton were found.

Gillum and Armijo (1997) mentioned that seed cotton cleaning efficiency was different due to treatment, ranging from 53.9 to $83.0 \%$. This was an overall cleaning efficiency based on the amount of trash in the seed cotton before and after cleaning. This efficiency also included performance of separators.

Adel-Salam (1999) stated that mechanical action of seed cotton cleaners had adverse affects on some fiber properties especially length, but, on the contrary, they had appositive effect on the lint grade because of removal of trash and foreign matter and better ginning preparation.

The Main objective of the present study is to minimize the foreign matters in Egyptian cotton to improve its quality and grade hence increase the national income. The study has been planned with the following specific objectives: a) To study the effect of mechanical and manual cotton harvesting methods on the fiber quality. b) To study the effect of cleaning operation and extracting the foreign matter on ginning efficiency and fiber quality. c) To 
evaluate the quality of the ginned cotton as affected by seed cotton moisture content, feed rate and knife moving speed for gin stand.

Gordon (2001) concluded that harsh ginning conditions increased neps and reduced the size trash particles. The smaller trash is not easily removed and become a problem, particularly in open end. Spinning (OE-spinning).

Dunna et al. (2002) mentioned that lint cleaner and fiber quality relationships (non-lint content, lint cleaner efficiency, fiber strength, micronaire reading, fibergraph length, uniformity ratio, percentage of lint in gin waste, colorimeter reflectance, and colorimeter plus) by using recent experimental data. These relationships provide a means to evaluate the effects of alternative gin configurations and initial cotton properties on ginning performance and to identify a machine sequence in the ginning process that would optimize quality characteristics of the saleable fiber.

El-Awady et al. (2002) shown that feeding gin stand with seed cotton at $0.7 \mathrm{rpm}(0.022 \mathrm{~m} / \mathrm{s})$ exhibited the highest gin stand capacity. However, at feeder speed above or below $0.7 \mathrm{rpm}$ the gin stand capacity gradually decrease as a result of shockage. This result was true for all cotton varieties.

Byler (2006) indicated that single fiber breaking force increased with increased moisture content in the range of 3 to $15 \%$, while fiber seed attachment forces remain constant when moisture content ranged from 3 to $11 \%$ and then decrease up to $15 \%$. These data provided an explanation for why ginning at higher moisture content improved fiber length quality.

Boykin (2007) said that, the gin stand energy requirements were lower for cultivars with large seed and low seed linters content. Ginning energy did not change with fiber length, but it increased with short fiber content as more fibers were broken in multiple places. Cultivars that used less energy during ginning tended to have higher HVI fiber strength, so reduced fiber-seed bond strength was not the result of reduced fiber strength. Ginning energy increased with the number of neps, number of seed coat neps, and weight of seed coat fragments, and it decreased with seed cotton cleaner efficiency.

Kabel (2007) stated that cotton cleaning efficiency increased by increasing saw drum speed and decreasing moisture content while, it was decreased by increasing feed rate.

\section{MATERIALS AND METHODS}

This investigation was carried out during 2006/2007 which includes (cleaning and ginning processes). Cleaning process was carried out at Rice Mechanization Center, Meet El-Deeba, Kafr El-Sheikh Province by using cleaning machine designed by Kabel (2007). While, ginning process was carried out at the Cotton Ginning Research Division Lab (CGRD), Sakha Agriculture Research Center, Cotton Research Institute (CRI), Kafr El-Sheikh Province by using ginning prototype machine. 
Khalifa E. M. et al.

1- Materials

a) The cotton crop: The tested seed cotton crop used in these experiments was Giza 86 variety which harvested by using two different methods, cotton piker and manual (hand picking) during summer season 2005 at El-Karada Farm, Agriculture Ministry, Kafr El-Sheikh Governorate. It ranks first in the volume of exports, and is a strong competitor of US Pima.

b) Cotton harvesting machine: cotton mechanical harvesting was undertaken by using picker harvester JOHN DEERE 9970.

c) Cleaning machine: It is consist of frame mechanical loader impurity remover (impact drums, $30 \mathrm{~cm}$ diameter and $100 \mathrm{~cm}$ length), saw drums, 100 $\mathrm{cm}$ length and doffing drums. The impurity remover (impact drums) is used to rip seed cotton, shell (open) closed bolls and to remove small impurities. Also, waste auger was used with diameter $20 \mathrm{~cm}$ to extract wastes. Naser tractor of $60 \mathrm{hp}(49.1 \mathrm{~kW})$ was used for operating cotton extractor in cleaning experiments with three rotational speeds. The minimum and maximum engine speeds were 1000 and $2200 \mathrm{rpm}$ with an average diesel specific fuel consumption of $0.775 \mathrm{l} / \mathrm{kW}$.h.

d) The gin stand: The reciprocating-knife gins of McCarthy $20 \mathrm{~cm}$ length. The adjustment of moving parts of gin stand machine was set according to the conventional settings, which is usually followed with respect to each variety and grad. The power source of the machine is electricity. The input power was controlled by a potentiometer to adjust the operating speed. The speeds of different moving parts of the gin stand were fixed and measured by a speedometer. Fig. 1 shows a schematic diagram of conventional (McCarthy) gin stand machine.

e) Measuring instruments:

Performance evaluation: Performance of the ginning machine was evaluated using the following parameters: i) Moving knife speed: Four speeds were used in the present study: $600,650,700$ and r.p.m (8.62, 9.41, 10.2 and $10.99 \mathrm{~m} / \mathrm{s}$ ). tachometer was used to measure the speeds of rotational speed of moving knife. ii) Feeding rate of seed cotton: three feeding rates were used 6,9 and $12 \mathrm{~kg} / \mathrm{h}$. seed cotton was fed by hand to the gin stand machine during ginning process. iii) Moisture content of seed cotton: three different cotton moisture content were used, $5.70,7.56$ and $10.32 \%$ (w.b). The moisture of cotton seeds were measured by using drying oven which set at $110 \pm 1{ }^{\circ} \mathrm{C}$ for $20 \mathrm{~min}$. iv) The ginning operation was carried out on the manually and mechanically harvested cotton. The experiments were carried out with three replicates to evaluate the ginning performance in the following terms: Cleaning efficiency, ginning outturn, gin stand capacity, ginning efficiency, energy consumption of ginning machine and fiber properties. The present active sample of lint was taken randomly and tested at the Cotton Technology Research Division (CTRD) ARC. 


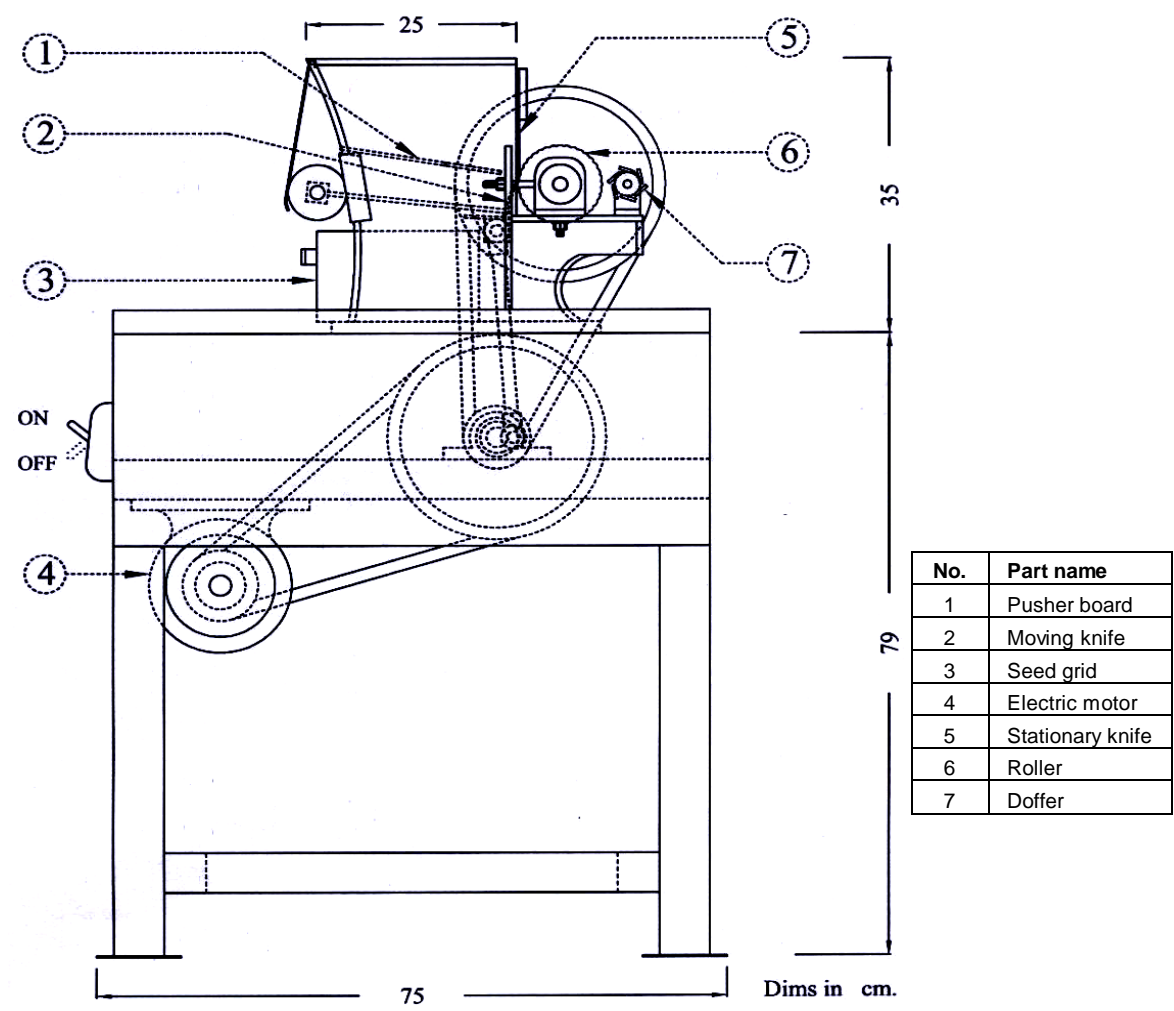

Fig. 1: A schematic diagram of conventional (McCarthy) gin stand.

\section{2- Methods:}

a) Cleaning processes: The cleaning machine was operated with saw drum speed of 600 r.p.m. $(9.41 \mathrm{~m} / \mathrm{s})$ at feed rate of $17.5 \mathrm{~kg} / \mathrm{min}$ and moisture content of about $5.7 \%$ for cotton fiber. The cotton used for cleaning operation was harvested mechanically by picker. It should be noted that, the manual harvested cotton doesn't subject to cleaning operation.

\section{b) Laboratory testing :}

Cleaning efficiency, $\%=\frac{\text { Sample mass before cleaning, } \mathrm{kg}-\text { Trash mass, } \mathrm{kg}}{\text { Sample mass before cleaning, } \mathrm{kg}} \times 100--1$

Ginning outturn, $\%=\frac{\text { Lint mass, } \mathrm{kg}}{\text { Seed cotton mass, } \mathrm{kg}} \times 100$

Gin stand capacity, $\mathrm{kg} / \mathrm{m} . \mathrm{h}=\frac{\text { Lint mass, } \mathrm{kg}}{\text { Length of roller, } \mathrm{m}} \times \frac{60}{\text { Ginning time, } \min }$

Ginning efficiency, $\%=\frac{\text { Sample mass before ginning, } \mathrm{kg} \text { - Seed wastagemass, } \mathrm{kg}}{\text { Sample mass before ginning, } \mathrm{kg}} \times 100$ where, seed wastage mass is seed cotton mass without ginning. 
Fiber properties: were determined under standard conditions of temperature $\left(21.1^{\circ} \mathrm{C} \pm 1\right)$ and relative humidity $(65 \% \pm 2)$.

Fiber length: Digital fibrograph was used to measure fiber length according to the standard method of ASTM (1984) designation D-1447-67. The $2.5 \%$ and $50 \%$ fiber span length were determined directly by the apparatus $(\mathrm{mm})$.

Uniformity, \%: It was determined accordance to ASTM (1984) designated D-1445-95, by using the following formula:

Uniformity ratio (U.R.) $=\frac{50 \% \text { Span fiber length }}{2.5 \% \text { Span fiber length }} \times 100$---------------------- 5

Fiber strength and elongation : The stelometer was used to determine the fiber strength and elongation at breaking load of cotton fiber as flat bundle at $1 / 8$ inch $(3.18 \mathrm{~mm})$ gauge length according to the standard procedure designated secured in clamps spaced $1 / 8$ inch, cut to a by the ASTM, (1984) d-1578 - 67. A bundle of fibers was combed parallel, known length and weight.

Fiber strength $(\mathrm{g} / \mathrm{tex})=\frac{\text { Breaking load }(\mathrm{g})}{\text { Bundle mass }(\mathrm{tex})}$

Where:

tex $=$ number of grams which weighted from $1 \mathrm{~km}$ length from fiber

Length of $1 \mathrm{~cm}$ from fiber $=150 \times 10^{-8} \mathrm{~g}$

Elongation percentage reads directly on the elongation indicator.

Color lint: It was determined by using high volume instrument (HVI). The (HVI) lines include an instrument that measures color in terms of two components reflectance ( $\mathrm{Rd}, \%)$ and yellowness $(+\mathrm{b})$. Where the HVI systems utilizes composite meter (Black and white video camera and color filtered silicon sensors) to measure both trash content and color.

Energy consumption of ginning machine: Ammeter and Voltmeter were used for measuring the current strength and potential difference, respectively of the gin stand machine. A switched potentiometer was used to control and change the operating speed of gin stand. Readings of ampere and volts were taken before and during each ginning treatments. The power consumption was calculated by using the following formula (Lockwood and Dunstan, 1971).

Total power consumption, $\mathrm{PC}=\frac{\mathrm{I} . \mathrm{V} \times \cos \theta}{1000}$ Where:

$\mathrm{PC}_{\mathrm{C}}=$ the electric power required by the gin stand, $\mathrm{kW}$

$\mathrm{I}$ = Electric current, Ampere;

$\mathrm{V}=$ Electric potential, Volt $(220 \mathrm{~V})$ and

$\operatorname{Cos} \theta=$ Power factor, equal 0.64 .

Hence, the energy requirements can be calculated as follows:

Energy requirements $=\frac{\text { Total power consumption }(\mathrm{W})}{\text { Productivity }(\mathrm{Mg} / \mathrm{h})}, \mathrm{W} . \mathrm{h} / \mathrm{Mg}------8$ 


\section{RESULTS AND DISCUSSION}

\section{Ginning capacity, $\mathrm{kg} / \mathrm{h}$. m:}

Figs. 2 illustrates the effect of fiber moisture content, seed cotton feed rate, ginning knife speed and harvesting methods on ginning capacity. For manual harvesting the results indicated that by increasing the ginning knife speed from 8.62 to $10.99 \mathrm{~m} / \mathrm{s}$ tends to decrease the ginning capacity from 8.99 to $8.64,8.34$ to 7.76 and 6.98 to $6.71 \mathrm{~kg} / \mathrm{h} . \mathrm{m}$ for fiber moisture contents of $5.70,7.56$ and $10.32 \%$, respectively and at seed cotton feed rate of $6 \mathrm{~kg} / \mathrm{h}$. The reason for that may be due to increase the amount of lint discharged with seeds; accordingly the ginning capacity will decrease. In the same manner the increase of seed cotton feed rate from 6 to $12 \mathrm{~kg} / \mathrm{h}$ leads to increase the ginning capacity from 8.99 to $16.93,8.34$ to 15.26 and from 6.98 to 13.44 $\mathrm{kg} / \mathrm{h} . \mathrm{m}$ at ginning knife speed of $8.62 \mathrm{~m} / \mathrm{s}$ and fiber moisture contents of 5.7 , 7.56 and $10.32 \%$, respectively. Increasing the feed rate leads to increase the ginning capacity, this may be due to increase the amount of fibers per unit time.

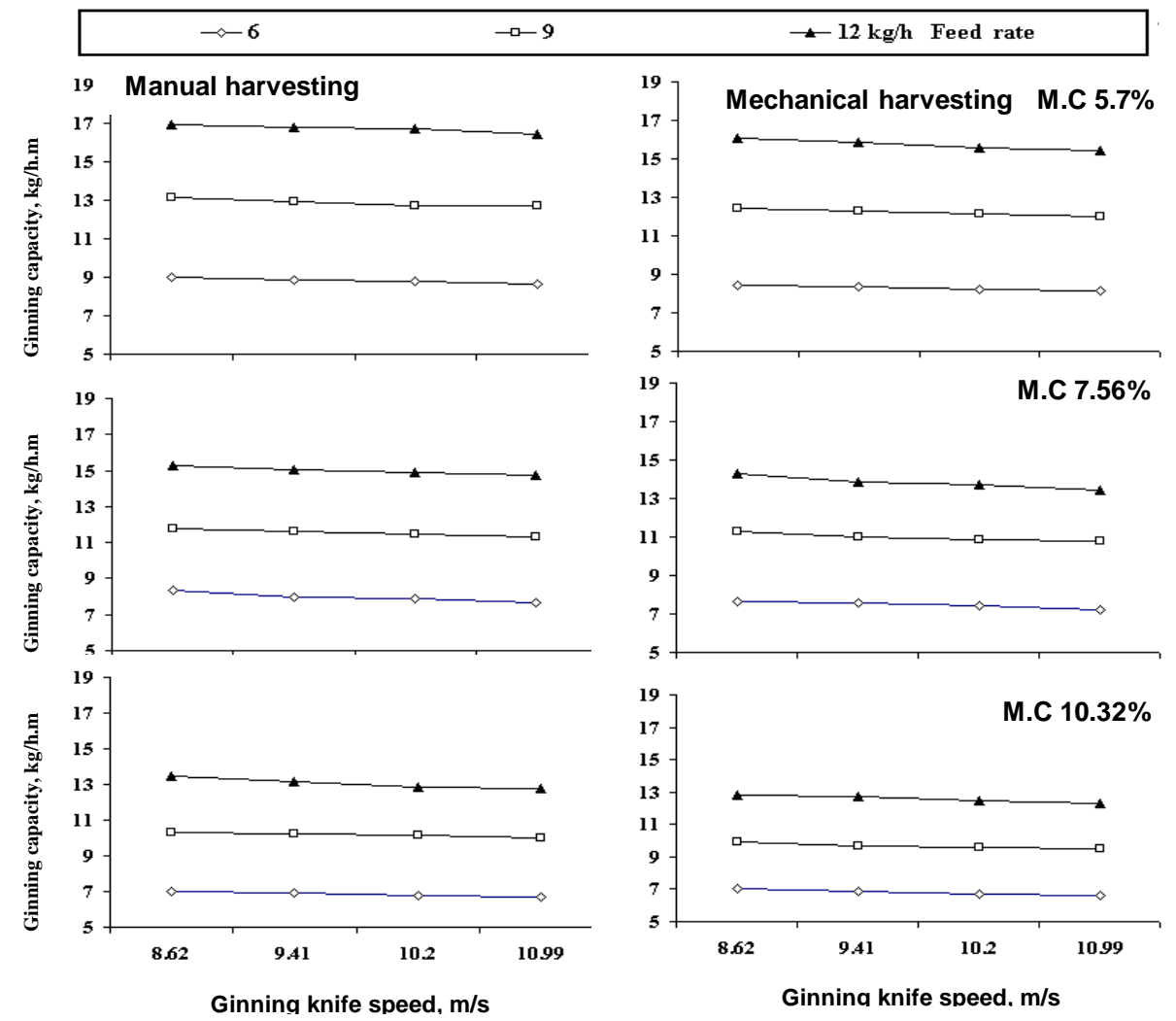

Fig. 2: Effect of ginning knife speed, feed rate and moisture content of cotton fiber on ginning capacity for manual and mechanical harvesting. 
Khalifa E. M. et al.

Results also showed that the increase of fiber moisture content from 5.70 , to $10.32 \%$ with seed cotton feed rate of $6 \mathrm{~kg} / \mathrm{h}$ and ginning knife speed of $8.62 \mathrm{~m} / \mathrm{s}$ leads to decrease the ginning capacity from 8.99 to $6.98 \mathrm{~kg} / \mathrm{h} . \mathrm{m}$. The same trend was observed with mechanical harvesting. This may be because of, with higher moisture content it is difficult to separate the lint from the seeds and consequently, increase the amount of lint discharged with seeds which leads to decrease the ginning capacity.

\section{Ginning outturn, \%:}

Fig. 3 illustrates the effect of fiber moisture content, seed cotton feed rate, ginning knife speed and harvesting methods on ginning outturn, \%. For manual harvesting the results indicated that increasing the ginning knife speed from 8.62 to $10.99 \mathrm{~m} / \mathrm{s}$ tends to decrease the ginning outturn from 44.95 to $43.22,41.70$ to 38.81 and 43.88 to $33.55 \%$ for fiber moisture contents $5.70,7.56$ and $10.32 \%$ at seed cotton feed rate of $6 \mathrm{~kg} / \mathrm{h}$. This may be due to increase the amount of lint lost with seeds which reduces the ginning outturn. Also, with higher moisture content there are some difficulties to separate the lint from seeds which increase the lint losses.

In the same manner the increase of seed cotton feed rate from 6 to $12 \mathrm{~kg} / \mathrm{h}$ leads to decrease the ginning outturn from 44.95 to $42.33,44.70$ to 38.17 and from 43.88 to $33.60 \%$ at fiber moisture contents of about $5.70,7.56$ and $10.32 \%$, respectively and ginning knife speed of $8.62 \mathrm{~m} / \mathrm{s}$. The same trend was observed with mechanical harvesting.

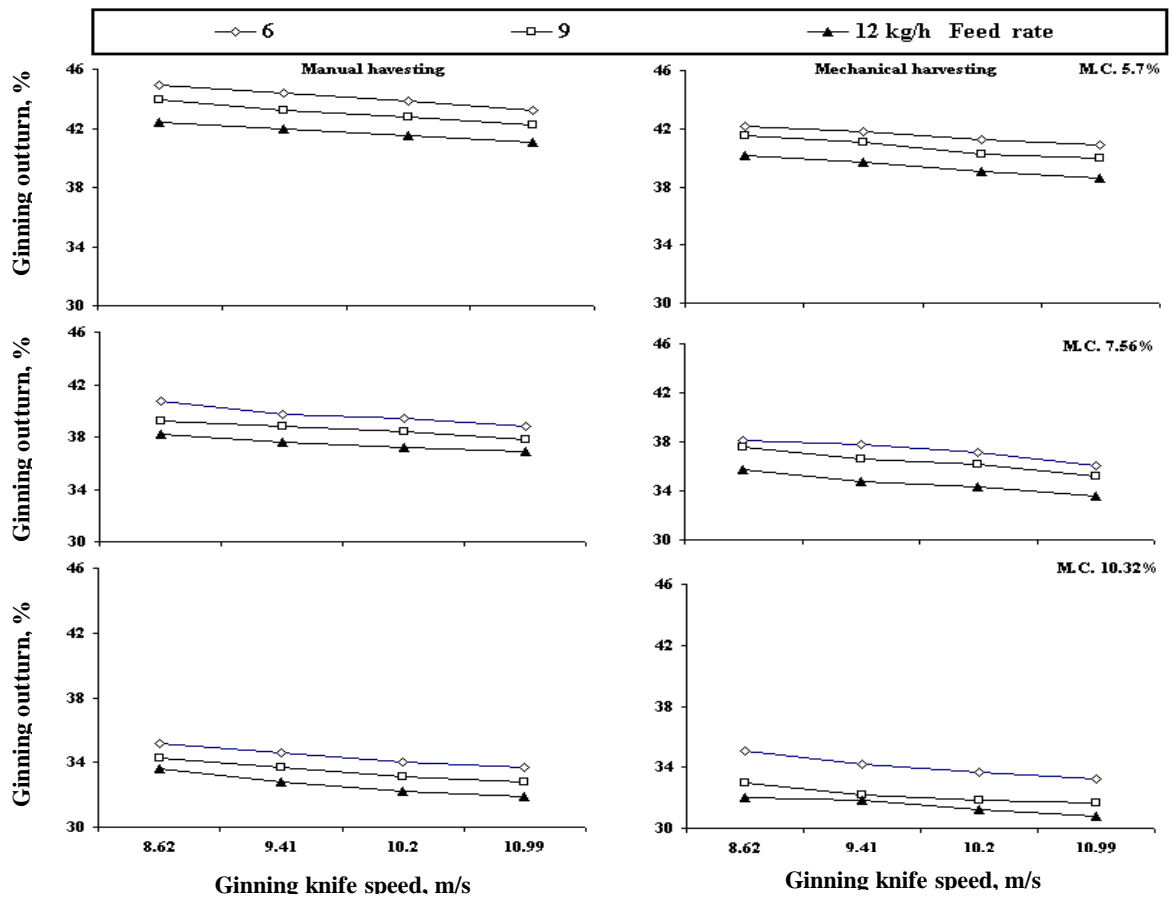

Fig. 3: Effect of ginnıng knıte speed, feed rate and moisture content of cotton fiber on ginning outturn for manual and mechanical harvesting. 
3. Ginning efficiency, \%:

Fig. 4 illustrates the effect of fiber moisture content, seed cotton feed rate, ginning knife speed and harvesting methods for the manual harvesting. The results showed that, increasing the ginning knife speed from 8.62 to $10.99 \mathrm{~m} / \mathrm{s}$ tends to decrease the ginning efficiency from 99.33 to $98.1,95.91$ to 94.6 and 90.81 to $89.35 \%$ for fiber moisture contents of $5.70,7.56$ and $10.32 \%$, respectively and seed cotton feed rate of $6 \mathrm{~kg} / \mathrm{h}$.

In the same manner the increase of seed cotton feed rate from 6 to 12 $\mathrm{kg} / \mathrm{h}$ leads to decrease the ginning efficiency from 99.33 to $98.44,95.94$ to 94.53 and 90.81 to $89.8 \%$ for fiber moisture contents of about $5.70,7.56$ and $10.32 \%$, respectively and ginning knife speed of $8.62 \mathrm{~m} / \mathrm{s}$. Also, the results indicated that by increasing fiber moisture content from 5.70 to $10.32 \%$ the ginning efficiency decreased from 99.33 to $98.3 \%$ at feed rate of $6 \mathrm{~kg} / \mathrm{h}$ and ginning knife speed of $8.62 \mathrm{~m} / \mathrm{s}$. The same trend was indicated with mechanical harvesting.

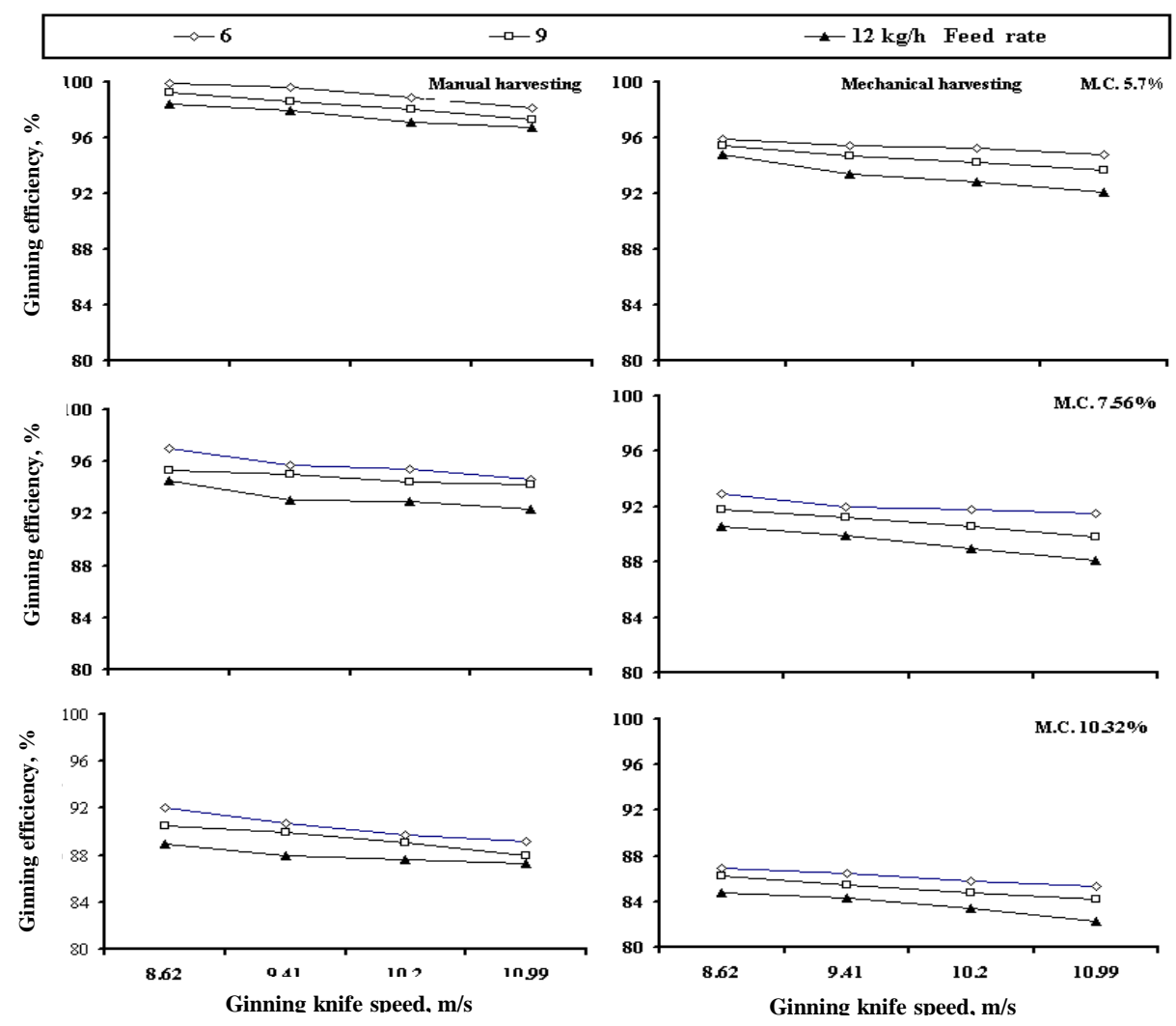

Fig. 4: Effect of ginning knife speed, feed rate and moisture content of cotton fiber on ginning efficiency for manual and mechanical harvesting. 
Khalifa E. M. et al.

Generally the increase of ginning knife speed, feed rate and fiber moisture content tends to increase the seed cotton wastage and accordingly reduce the ginning efficiency.

\section{Ginning energy consumption, W.h:}

Fig. 5 illustrates the effect of fiber moisture content, seed cotton feed rate, ginning knife speed and harvesting methods on ginning energy consumption. For manual harvesting the results showed that, increasing the ginning knife speed from 8.62 to $10.99 \mathrm{~m} / \mathrm{s}$ tends to increase the ginning energy consumption from 195.6 to $242.0,377.2$ to 412.0 and 556.0 to 598.4 W.h for moisture contents of $5.70,7.50$ and $10.32 \%$, respectively, at feed rate of $6 \mathrm{~kg} / \mathrm{h}$. The results also indicated that the increase of seed cotton feed rate from 6 to $12 \mathrm{~kg} / \mathrm{h}$ leads to increase the energy consumption from 4.89 to $280.0,377.2$ to 460.4 and 556.0 to 644.8 W.h for moisture content ranged from $5.70,7.56$ to $10.32 \%$, respectively at ginning knife speed of $8.62 \mathrm{~m} / \mathrm{s}$.

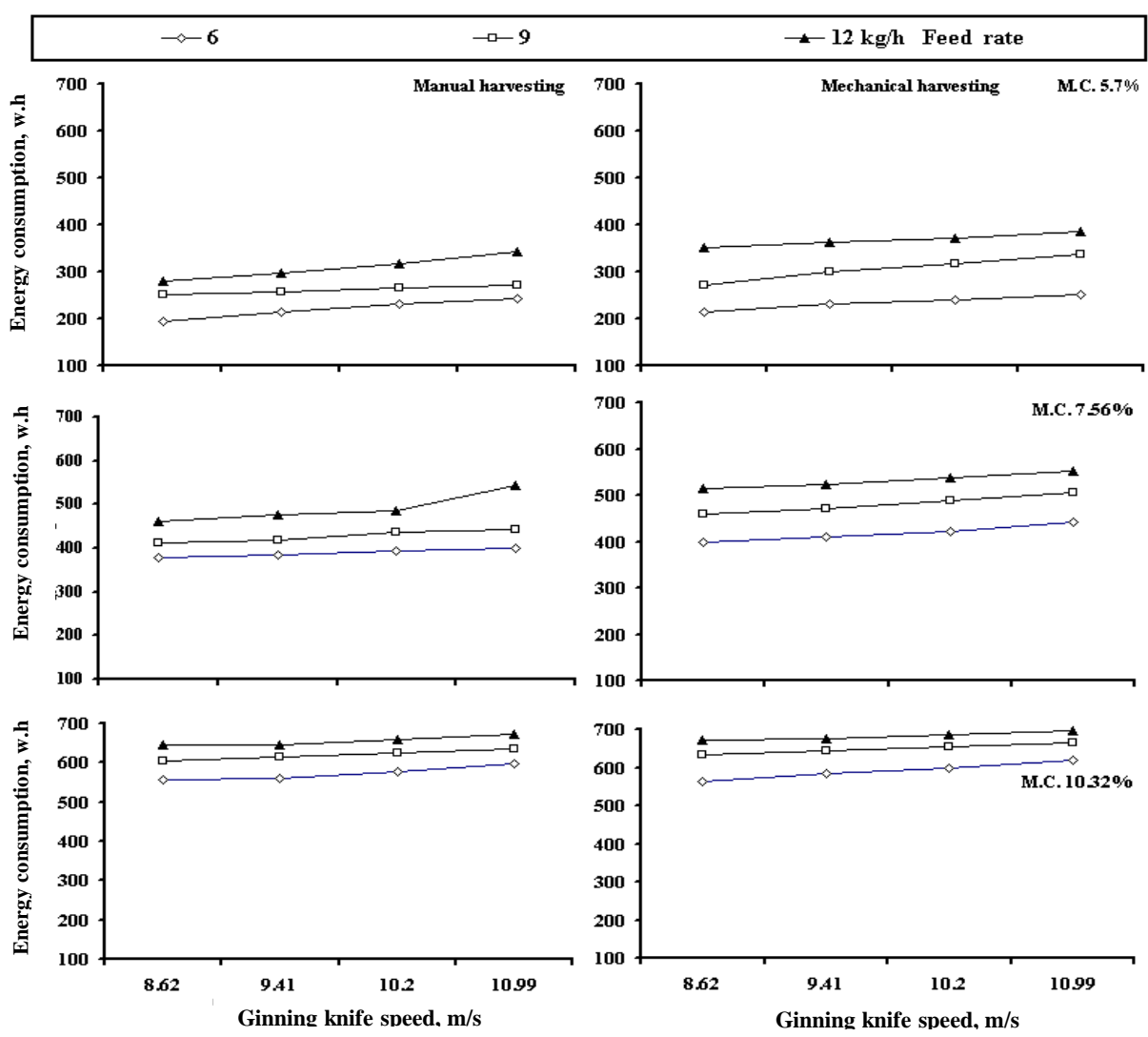

Fig. 5: Effect of ginning knife speed, feed rate and moisture content of cotton fiber on energy consumption for manual and mechanical harvesting. 
For manual harvesting, the results also showed that by increasing fiber moisture content from 5.70 to $10.32 \%$ the ginning energy consumption increased from 195.6 to 556.0 W.h at feed rate of $6 \mathrm{~kg} / \mathrm{h}$ and ginning knife speed of $8.62 \mathrm{~m} / \mathrm{s}$. The same trend was observed with mechanical harvesting 5. Physical fiber properties for cleaning and ginning operations:

Table 1 shows the fiber qualities and foreign matter of picking seed cotton at different levels of moisture content used in these experiments for manual and mechanical harvesting.

Table 1: Fiber properties of seed cotton after harvesting and cleaning

\begin{tabular}{|l|c|c|c|}
\hline \multicolumn{2}{|c|}{ Harvesting methods } & Manual harvesting & Mechanical harvesting \\
\hline \multirow{2}{*}{ Span fiber length, mm } & $2.50 \%$ & 35.6 & 33.4 \\
\cline { 2 - 4 } & $50 \%$ & 17.6 & 16 \\
\hline Uniformity, \% & 49.4 & 47.9 \\
\hline Color reflectance, \% & 70.1 & 69.2 \\
\hline Color yellowness, unit & 8.5 & 8.6 \\
\hline Trash content, \% & 4.17 & 4 \\
\hline Seed cotton elongation, & $\%$ & 4.3 & 5.9 \\
\hline Seed cotton strength, & g/tex. & 30.2 & 28.7 \\
\hline
\end{tabular}

\section{a. Fiber length uniformity, \%:}

Results listed in Table 2 show the effect of fiber moisture content, feed rate, ginning knife speed and harvesting methods on the fiber length uniformity. For manual harvesting it can be stated that uniformity decrease as the ginning knife speed increased from 8.62 to $10.99 \mathrm{~m} / \mathrm{s}$ at all different seed cotton feed rate and moisture content. Increasing the fiber moisture content from 5.70 to $10.32 \%$ at ginning knife speed of 8.62 and $10.99 \mathrm{~m} / \mathrm{s}$ and seed cotton feed rate of $6 \mathrm{~kg} / \mathrm{h}$ leads to decrease the uniformity from 46.90 to 46.0 and 49.70 to $47.20 \%$, respectively.

Table 2: Effect of ginning knife speed, feed rate and fiber moisture content on fiber length uniformity, \%, for manual and mechanical harvesting.

\begin{tabular}{|c|c|c|c|c|c|c|c|c|c|}
\hline \multirow{2}{*}{$\begin{array}{c}\text { Moisture } \\
\text { content, \% }\end{array}$} & \multirow{2}{*}{$\begin{array}{c}\text { Feed } \\
\text { rate, kg/h } \mathbf{h}\end{array}$} & \multicolumn{4}{|c|}{ Manual harvesting } & \multicolumn{4}{c|}{ Mechanical harvesting } \\
\cline { 3 - 10 } & & 8.62 & 9.41 & 10.2 & 10.99 & 8.62 & 9.41 & 10.2 & 10.99 \\
\hline \multirow{3}{*}{5.70} & 6 & 46.9 & 46.6 & 46.2 & 46.1 & 47.1 & 47.0 & 46.2 & 46.0 \\
& 9 & 47.6 & 47.4 & 47.0 & 46.9 & 47.6 & 47.5 & 47.3 & 47.0 \\
& 12 & 47.9 & 47.8 & 47.7 & 47.0 & 47.8 & 47.5 & 47.4 & 47.2 \\
\hline \multirow{3}{*}{7.56} & 6 & 49.3 & 49.0 & 48.6 & 48.2 & 47.4 & 46.8 & 46.5 & 46.1 \\
& 9 & 49.8 & 49.6 & 49.3 & 49.0 & 47.6 & 47.1 & 46.7 & 46.5 \\
& 12 & 49.9 & 49.8 & 49.5 & 49.2 & 47.9 & 47.8 & 47.7 & 47.6 \\
\hline \multirow{3}{*}{10.32} & 6 & 49.7 & 48.3 & 47.6 & 47.2 & 48.1 & 47.4 & 47.0 & 46.7 \\
& 9 & 49.8 & 49.1 & 47.9 & 47.6 & 48.6 & 47.89 & 47.7 & 47.4 \\
& 12 & 49.9 & 49.4 & 48.9 & 48.5 & 48.8 & 48.0 & 47.9 & 47.6 \\
\hline
\end{tabular}

Each reading indicated through the table is the average of three replicates readings.

The results also indicated that by increasing the feed rate from 6 to 12 $\mathrm{kg} / \mathrm{h}$ the uniformity increases from 46.9 to 47.9 and from 49.9 to $47.2 \%$ at ginning knife speed of $8.62 \mathrm{~m} / \mathrm{s}$ and fiber moisture contents of 5.70 and 
$10.32 \%$, respectively. However increasing the fiber moisture content from 5.70 to 10.32 the uniformity increase from 46.9 to $49.7 \%$ at feed rate $6 \mathrm{~kg} / \mathrm{h}$ and ginning knife speed of $8.62 \mathrm{~m} / \mathrm{s}$. Regarding to mechanical harvesting the tendency was observed as obtained with manual harvesting under the same operating conditions.

\section{b. Color reflectance $(\mathbf{R d}) \%$ :}

Results listed in Table 3 observed the effect of fiber moisture content, feed rate, ginning knife speed and harvesting methods on color reflectance (Rd), \%. For manual harvesting it was observed that the color reflectance increased as the ginning knife speed increased from 8.62 to $10.99 \mathrm{~m} / \mathrm{s}$ at all different feed rates and fiber moisture contents. Dealing with the increase of the ginning knife speed from 8.62 to $10.99 \mathrm{~m} / \mathrm{s}$ with feed rate of $6 \mathrm{~kg} / \mathrm{h}$ and fiber moisture content ranged from 5.70 to $10.32 \%$ the color reflectance increased from 71.6 to 72.6 and from 70.70 to $71.90 \%$, respectively.

Table 3: Effect of ginning knife speed, feed rate and moisture content of cotton fiber on color reflectance (Rd), \%, for manual and mechanical harvesting

\begin{tabular}{|c|c|c|c|c|c|c|c|c|c|}
\hline \multirow{3}{*}{$\begin{array}{c}\text { Moisture } \\
\text { content, \% }\end{array}$} & \multirow{3}{*}{$\begin{array}{l}\text { Feed } \\
\text { rate, } \\
\mathrm{kg} / \mathrm{h}\end{array}$} & \multicolumn{4}{|c|}{ Manual harvesting } & \multicolumn{4}{|c|}{ Mechanical harvesting } \\
\hline & & \multicolumn{4}{|c|}{ Ginning knife speed, m/s } & \multicolumn{4}{|c|}{ Ginning knife speed, m/s } \\
\hline & & 8.62 & 9.41 & 10.2 & 10.99 & 8.62 & 9.41 & 10.2 & 10.99 \\
\hline \multirow{3}{*}{5.70} & 6 & 71.6 & 72.1 & 72.3 & 72.6 & 71.8 & 72.3 & 72.6 & 72.9 \\
\hline & 9 & 71.2 & 71.7 & 71.9 & 72.3 & 71.4 & 71.9 & 72.1 & 72.5 \\
\hline & 12 & 70.9 & 71.4 & 71.8 & 72.2 & 71.1 & 71.3 & 71.7 & 72.2 \\
\hline \multirow{3}{*}{7.56} & 6 & 70.8 & 71.3 & 71.5 & 72.0 & 71.0 & 71.5 & 71.8 & 72.3 \\
\hline & 9 & 70.6 & 71.0 & 71.4 & 71.5 & 70.4 & 70.9 & 71.4 & 71.8 \\
\hline & 12 & 70.1 & 70.5 & 70.8 & 71.2 & 70.0 & 70.0 & 70.8 & 71.3 \\
\hline \multirow{3}{*}{10.32} & 6 & 70.7 & 71.0 & 71.4 & 71.9 & 70.8 & 71.0 & 71.8 & 72.0 \\
\hline & 9 & 70.2 & 70.5 & 70.8 & 71.3 & 69.9 & 70.4 & 71.0 & 71.3 \\
\hline & 12 & 69.7 & 70.0 & 70.4 & 70.6 & 69.2 & 69.7 & 70.4 & 70.9 \\
\hline
\end{tabular}

- Each reading indicated through the table is the average of three replicates readings.

The results also concluded that, by increasing seed cotton feed rate from 6 to $12 \mathrm{~kg} / \mathrm{h}$, the color reflectance decreases from 71.60 to 70.90 and from 70.70 to $69.70 \%$ at ginning knife speed $8.62 \mathrm{~m} / \mathrm{s}$ and fiber moisture contents of 5.70 and $10.32 \%$, respectively. However by increasing the fiber moisture content from 5.70 to $10.32 \%$ the color reflectance decreases from 71.60 to $70.7 \%$ at feed rate ranged from 6 to $12 \mathrm{~kg} / \mathrm{h}$ and ginning $\mathrm{knife}$ speed $8.62 \mathrm{~m} / \mathrm{s}$. Regarding to mechanical harvesting the tendency was observed as obtained with manual harvesting under the same operating conditions.

Result showed that, the increase of ginning knife speed tend to increase the color reflectance and this due to decrease the mount of trash content. In general increase both the feed rate and fiber moisture content increase of fiber moisture content make it difficult to separate the trash content and consequently reduces the color reflectance.

c. Fiber elongation, \%:

Table 4 summarizes the effect of fiber moisture content, seed cotton feed rate, ginning knife speed and harvesting methods on the percentage of 
fiber elongation. For manual harvesting, it can be stated that, the seed cotton elongation had increased as the ginning knife speed increased from 8.62 to $10.99 \mathrm{~m} / \mathrm{s}$ at all different seed cotton feed rates and fiber moisture contents. It was found that, the fiber strength increased from 4.7 to 5.8 and from 5.6 to $6.5 \%$ when the ginning knife speed increased from 8.62 to $10.99 \mathrm{~m} / \mathrm{s}$ and fiber moisture content increased from 5.70 to $10.32 \%$, respectively, at feed rate of $6 \mathrm{~kg} / \mathrm{h}$.

Table 4: Effect of ginning knife speed, seed cotton feed rate and moisture content of cotton fiber on fiber elongation, \%, for manual and mechanical harvesting

\begin{tabular}{|c|c|c|c|c|c|c|c|c|c|}
\hline \multirow{2}{*}{$\begin{array}{c}\text { Moisture } \\
\text { content, \% }\end{array}$} & Feed & \multicolumn{4}{|c|}{ Manual harvesting } & \multicolumn{4}{c|}{ Mechanical harvesting } \\
\cline { 3 - 9 } & $\mathbf{k g} / \mathbf{h}$ & \multicolumn{3}{|c|}{ Ginning knife speed, $\mathbf{s}$} & \multicolumn{3}{c|}{ Ginning knife speed, m/s } \\
\hline \multirow{3}{*}{5.70} & 6 & 4.7 & 5.0 & 5.6 & 5.8 & 6.3 & 6.8 & 6.9 & 7.0 \\
& 9 & 4.6 & 4.9 & 5.0 & 5.2 & 6.0 & 6.4 & 6.7 & 6.9 \\
& 12 & 4.0 & 4.2 & 4.6 & 4.8 & 5.8 & 6.0 & 6.4 & 6.8 \\
\hline \multirow{3}{*}{7.56} & 6 & 5.1 & 5.4 & 5.8 & 6.0 & 6.7 & 7.0 & 7.3 & 7.6 \\
& 9 & 4.7 & 5.0 & 5.3 & 5.7 & 6.3 & 6.7 & 6.9 & 7.3 \\
& 12 & 4.4 & 4.7 & 4.9 & 5.2 & 6.1 & 6.5 & 6.8 & 7.2 \\
\hline \multirow{3}{*}{10.32} & 6 & 5.6 & 5.9 & 6.2 & 6.5 & 7.2 & 7.5 & 8.0 & 8.3 \\
& 9 & 5.3 & 5.8 & 6.0 & 6.3 & 6.7 & 6.9 & 7.3 & 7.5 \\
& 12 & 4.7 & 5.0 & 5.3 & 5.7 & 6.5 & 6.8 & 7.0 & 7.4 \\
\hline
\end{tabular}

- Each reading indicated through the table is the average of three replicates readings.

Also, it was noticed that, by increasing the seed cotton feed rate from 6 to $12 \mathrm{~kg} / \mathrm{h}$ the fiber strength decreased from 4.7 to 4.0 and from 5.6 to $4.7 \%$ at fiber moisture contents of 5.70 and $10.32 \%$ and ginning knife speed of 8.62 $\mathrm{m} / \mathrm{s}$. However increasing the fiber moisture content from 5.70 to $10.32 \%$ the fiber strength increases from 4.7 to $5.6 \%$ at seed cotton feed rate of $6 \mathrm{~kg} / \mathrm{h}$ and ginning knife speed of $8.62 \mathrm{~m} / \mathrm{s}$. Regarding to the mechanical harvesting the same observation was obtained with manual harvesting under the same above mentioned operating conditions.

\section{d. Fiber strength, g/tex. :}

Results listed in Table 5 indicated the effect of fiber moisture content, fiber feed rate, ginning knife speed and harvesting methods on seed cotton strength. For manual harvesting, it was found that, seed cotton strength decreased as the ginning knife speed increased from 8.62 to $10.99 \mathrm{~m} / \mathrm{s}$ at all different levels of seed cotton feed rates and fiber moisture contents. The recorded results revealed that, the fiber strength decreased from 29.0 to 28.2 and from 29.60 to $28.60 \mathrm{~g} / \mathrm{tex}$ when ginning knife speed increased from 8.62 to $10.99 \mathrm{~m} / \mathrm{s}$ and fiber moisture content increased from 5.70 to $10.32 \%$, respectively at feed rate of $6 \mathrm{~kg} / \mathrm{h}$. Also by increasing seed cotton feed rate from 6 to $12 \mathrm{~kg} / \mathrm{h}$ the fiber elongation increased from 29.0 to 29.80 and from 29.60 to $30.20 \mathrm{~g} / \mathrm{tex}$ at fiber moisture contents of 5.70 to $10.32 \%$, respectively and ginning knife speed of $8.62 \mathrm{~m} / \mathrm{s}$.

However by increasing the fiber moisture content from 5.70 to $10.32 \%$, the fiber strength increased from 29.0 to $29.6 \mathrm{~g} / \mathrm{tex}$ at seed cotton feed rate 6 $\mathrm{kg} / \mathrm{h}$ and ginning knife speed $8.62 \mathrm{~m} / \mathrm{s}$. Regarding to mechanical harvesting 
with cleaning at speed of $9.41 \mathrm{~m} / \mathrm{s}$, it had the same observation as obtained with manual harvesting under the same operating conditions.

Table 5: Effect of ginning knife speed, seed cotton feed rate and moisture content of cotton fiber on fiber strength, $g /$ tex, for manual and mechanical harvesting

\begin{tabular}{|c|c|c|c|c|c|c|c|c|c|}
\hline $\begin{array}{c}\text { Moisture } \\
\text { content, } \\
\%\end{array}$ & \multirow{2}{*}{$\begin{array}{c}\text { Feed } \\
\text { rate, kg/h } \mathbf{h}\end{array}$} & \multicolumn{4}{|c|}{ Manual harvesting } & \multicolumn{3}{c|}{ Mechanical harvesting } \\
\cline { 3 - 9 } & & 8.62 & 9.41 & 10.2 & 10.99 & 8.62 & 9.41 & 10.2 & 10.99 \\
\hline \multirow{3}{*}{5.70} & 6 & 29.0 & 28.7 & 28.5 & 28.2 & 28.3 & 28.0 & 27.8 & 27.5 \\
& 9 & 29.4 & 29.0 & 28.7 & 28.4 & 28.6 & 28.4 & 28.3 & 28.0 \\
& 12 & 29.8 & 29.6 & 29.5 & 29.1 & 28.7 & 28.6 & 28.4 & 28.2 \\
\hline \multirow{3}{*}{7.56} & 6 & 29.3 & 29.0 & 28.8 & 28.5 & 28.8 & 28.5 & 28.2 & 28.0 \\
& 9 & 29.7 & 29.4 & 29.0 & 28.7 & 28.9 & 28.7 & 28.4 & 28.2 \\
& 12 & 29.9 & 29.5 & 29.3 & 28.9 & 29.3 & 29.1 & 28.8 & 28.5 \\
\hline \multirow{4}{*}{10.32} & 6 & 29.6 & 29.2 & 28.9 & 28.6 & 29.1 & 28.9 & 28.7 & 27.9 \\
& 9 & 29.8 & 29.4 & 29.0 & 28.8 & 29.3 & 29.0 & 28.8 & 28.6 \\
& 12 & 30.2 & 29.8 & 29.5 & 29.4 & 29.5 & 29.4 & 29.3 & 28.9 \\
\hline
\end{tabular}

Each reading indicated through the table is the average of three replicates reading.

Results indicated that, increasing the ginning knife speed tends to destroy the fiber and reduces the fiber strength, but increasing the feed rate makes a protection for the cotton fiber and reduces the fiber strength.

\section{Conclusion}

The following conclusions are derived from the study:

1. The highest value of ginning stand capacity was about $16.93 \mathrm{~kg} / \mathrm{h} . \mathrm{m}$ for manual harvesting at ginning knife speed of $8.62 \mathrm{~m} / \mathrm{s}$; feed rate of 12 $\mathrm{kg} / \mathrm{h}$ and fiber moisture content of $5.70 \%$.

2. The maximum value of ginning outturn and ginning efficiency were about $44.95 \%$ and $99.33 \%$, respectively for manual harvesting at ginning knife speed of $8.62 \mathrm{~m} / \mathrm{s}$, seed cotton feed rate of $6 \mathrm{~kg} / \mathrm{h}$ and fiber moisture content of $5.70 \%$.

3. The minimum value was about 195.7 W.h for manual harvesting at ginning knife speed of $8.62 \mathrm{~m} / \mathrm{s}$, seed cotton feed rate of $6 \mathrm{~kg} / \mathrm{h}$ and fiber moisture content of $5.70 \%$.

4. The maximum value of seed cotton fiber uniformity was about $49.9 \%$ at ginning knife speed of $8.62 \mathrm{~m} / \mathrm{s}$, seed cotton feed rates of $12 \mathrm{~kg} / \mathrm{h}$ for manual harvesting. Meanwhile, the highest value of color reflectance was about $72.9 \%$ at ginning knife speed of $10.99 \mathrm{~m} / \mathrm{s}$, seed cotton feed rate of $6 \mathrm{~kg} / \mathrm{h}$ and fiber moisture content of $5.7 \%$ for mechanical harvesting

5. The minimum value of fiber elongation of $4 \%$ was recorded at ginning knife speed of $8.62 \mathrm{~m} / \mathrm{s}$, seed cotton feed rate of $12 \mathrm{~kg} / \mathrm{h}$ and fiber moisture content of $5.70 \%$ for manual harvesting. Whereas, the highest value of seed cotton strength of $30.2 \mathrm{~g} / \mathrm{tex}$ was observed at ginning knife speed of $8.62 \mathrm{~m} / \mathrm{s}$, seed cotton feed rate of $12 \mathrm{~kg} / \mathrm{h}$ and fiber moisture content of $10.32 \%$ for manual harvesting. 
6. The best performance for the gin stand machine were obtained at rotational speed of 600 r.p.m, feed rate of $6 \mathrm{~kg} / \mathrm{h}$ and fiber moisture of $5.7 \%$ where it gave the following results: a) ginning capacity of 16.93 $\mathrm{kg} / \mathrm{h} . \mathrm{m}$. b) ginning outturn of $44.95 \%$. c) ginning efficiency of $99.33 \%$, and d) ginning energy consumption of about 195.6 w.h.

7. Whereas the best fiber qualities were obtained at rotational speed of 600 r.p.m, feed rate $12 \mathrm{~kg} / \mathrm{h}$ and fiber moisture of about $10.32 \%$ and the following indicators were obtained: a) Fiber uniformity of $49.9 \%$. b) fiber elongation of $4 \%$. c) fiber strength of $30.2 \mathrm{~g} / \mathrm{tex}$, and d) color reflectance of $72.9 \%$.

8. The study strongly recommended to use mechanical harvesting for cotton followed by cleaning due to the labour shortage during the harvesting time where it improves some fiber qualities.

\section{REFERENCES}

Adel Salam, M.E. (1999). Effect of ginning process on fiber quality the Egyptian cotton, Elkalema press, Giza, Cairo: 403P.

ASTM. (1984). American society for testing and materials. Standards of textile Testing and materials. Society, Philadelophia, USA.

Boykin, J.C. (2007). Cultivar differences in gin stand energy utilization. Trans. of the ASAE, 50 (3): 733-743.

Byler, R.K. (2006). Historical review on the effect of moisture content and addition of moisture to seed cotton before ginning on fiber length. Journal of Cotton Science, 10: 300-310.

Dunna, T.A.; S.K. Misra and G.L. Baker (2002). Predicting lint cleaner efficiency and fiber quality characteristics cotton ginning. Applied Eng. Agric., 18 (2): 141-146.

El-Awady, M.N.; M.M. Youssef and H.E. El-Feky (2002). Design new seed cotton feeder for reciprocating knife gin stand. Misr Agric. Eng., 16-17. Misr, J. Ag. Eng., 5 (4): 329-343.

Eweida, M.A. (1997). Cotton ginning efficiency as affect with methods feeding the gin stand with seed cotton. Egyptian J. App. Sc., 21(11): 203-208.

Gillum, M.N. and C.B. Armijo (1997). Pima seed cotton cleaning for maximum profit. Trans. of the ASAE, 40 (3): 513-518

Gordon, S. (2001). Cotton fiber quality research needs the Australian perspective. Textile Institute $81^{\text {st }}$ World conference on An Odyssey in fiber and space, Melbourne, Australia, April CSIRO Textile and fiber Tec. : $1-9$.

Kabel, A.Z. (2007). Manufacturing and performance evaluation of a small machine for cleaning mechanical harvested seed cotton. Ph.D. Thesis. Fac. of Agric., Kafrelsheikh Univ.

Lockwood, F.B. and R. Dunstan (1971). Electric engineering principles. Meine Man Educational Book, London.

Mangialardi, G.J. (1986). An Alternative methods for determining lint cleaner efficiency. Trans. of the ASAE, 29 (1): 288-293. 
Khalifa E. M. et al.

Mangialardi, G.J. and W.R. Meredith (1990). Relationship of fineness maturity and strength to nep and seed coat fragments in ginned lint. Trans. of the ASAE, 33 (4): 1075-1082.

Munro. J. M. (1987). Cotton. Ministry of Agric., Press Cairo, Egypt.

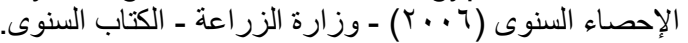

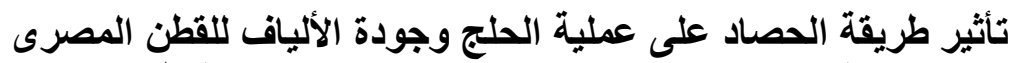

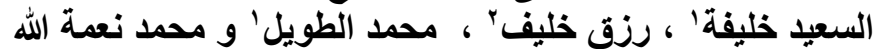

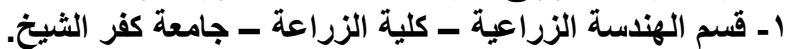
r ـ ـ معه بحوث الهندسة الزراعية ــ الجيزة - مصر.

تعتبر مصر فى مقدمة الدول المصدرة للأقطان طويلة التيلة فى العالم حيث تتنج ربع إنتاج

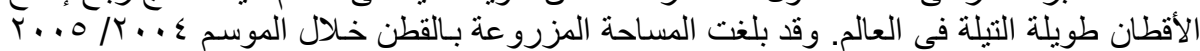

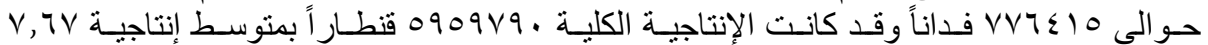

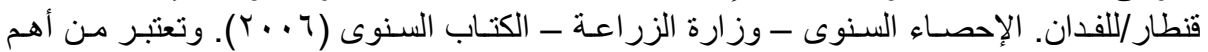

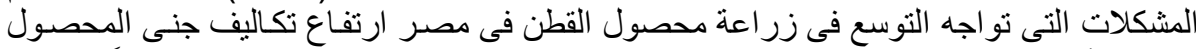

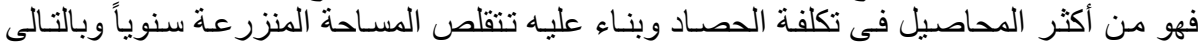

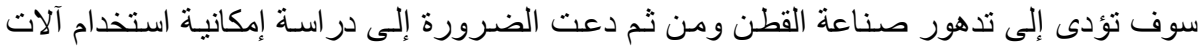

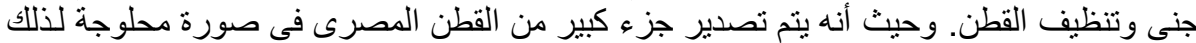

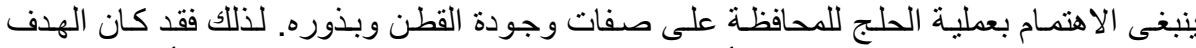

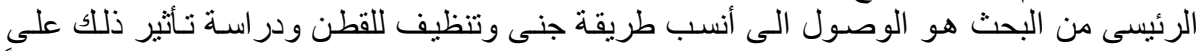

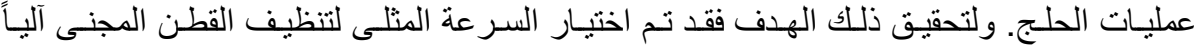

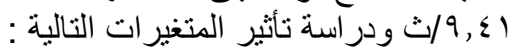

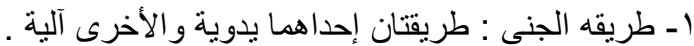

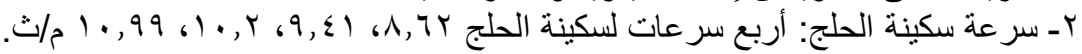

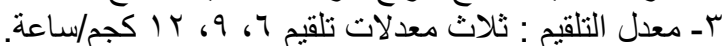

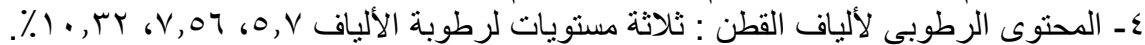

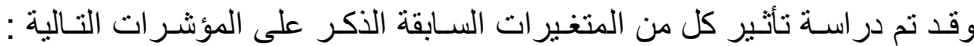

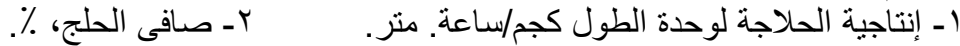

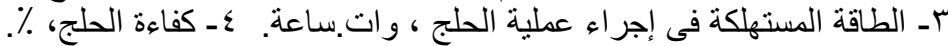

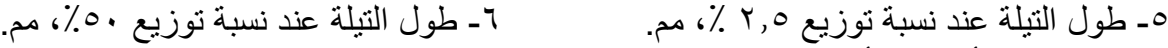

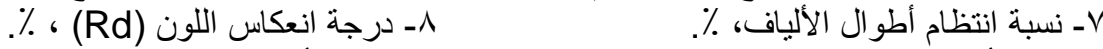

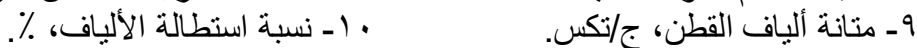

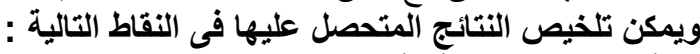

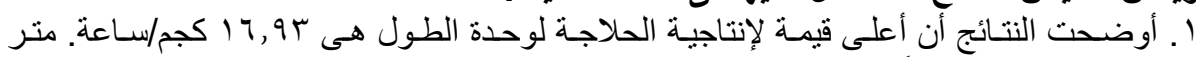

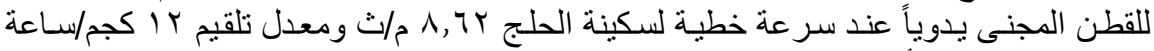

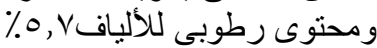

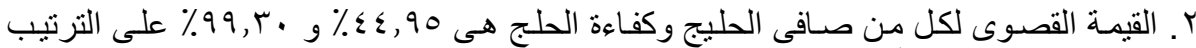

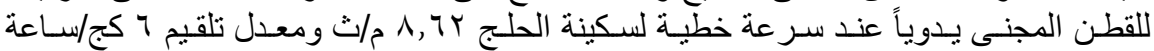

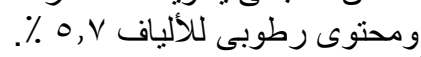

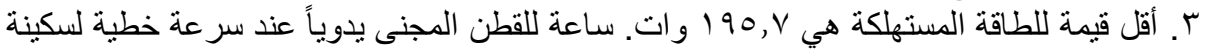

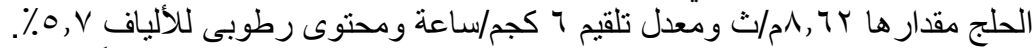

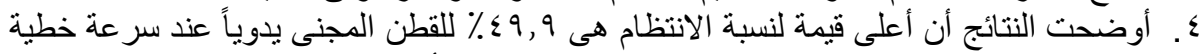

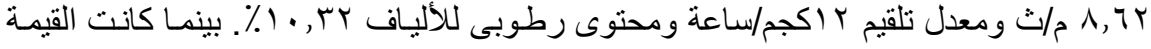




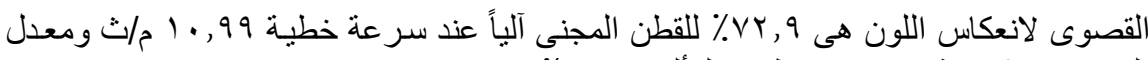

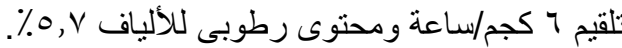

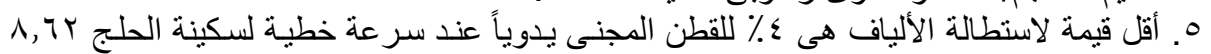

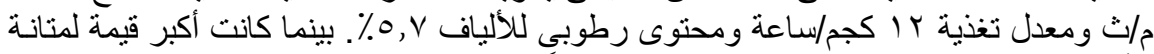

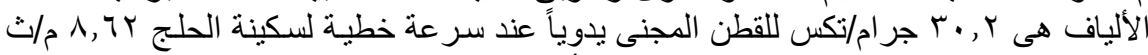

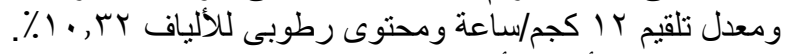

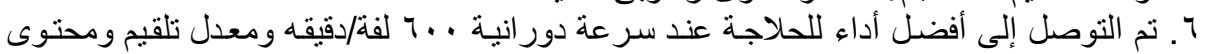

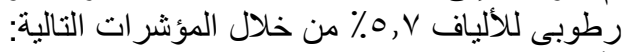

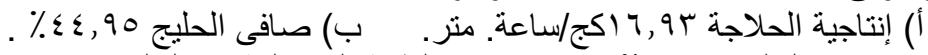

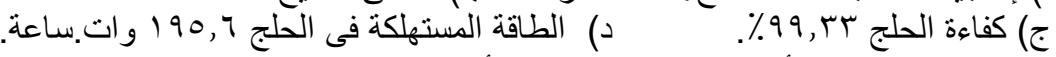

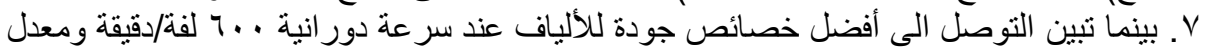

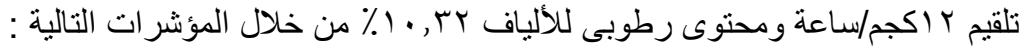

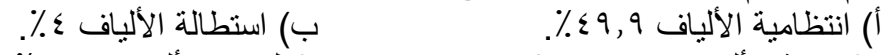

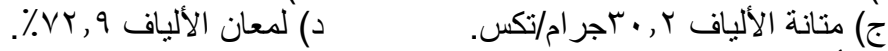

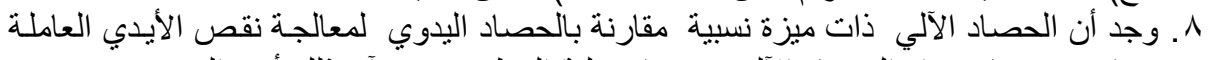

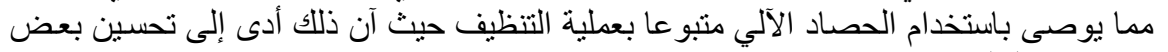
خصائص التيلة. 